\title{
Fortelling fra praksis som inngang til pedagogisk kunnskap
}

Praksisfortelling som undervisningspraksis og læringsform i lærerutdanningen

\author{
Marianne Leikvoll Eide* og May-Britt Revheim Brekke \\ Høgskolen på Vestlandet, Norge
}

\begin{abstract}
Denne artikkelen bygger på utprøving av praksisfortelling som studentaktiv læringsform. Noen av funnene, og erfaringene vi har gjort oss, trekkes her frem for å belyse hvordan fortellingen kan bidra til å skape sammenhenger mellom teori og praksis, sett fra vårt perspektiv som lærerutdannere. Fortelling fra praksis kan gjøre undervisningen på campus relevant og meningsfull for studentene når det tas utgangspunkt i studentenes egne erfaringer. Ulike kontekster møtes, og erfaringer kan deles på tvers av disse. I studentenes klasserom kan fortellingene endres og videreutvikles, og forforståelser og vanetenkning kan bli utfordret. For å kunne gripe fatt i, og spinne videre på, fortellinger og fortolkninger i det de kommer i undervisningen, kreves det nærvær og oppmerksom tilstedeværelse av faglærer.
\end{abstract}

Nøkkelord: praksisfortelling, teori/praksis, refleksjon, studentaktiv læringsform

\section{INNLEDNING}

Tema for denne artikkelen er praksisfortelling som læringsform i pedagogikkfaget, i en lærerutdanningskontekst. Vi reflekterer her over egne erfaringer og funn fra arbeidet med praksisfortelling som del av vår undervisningspraksis. Et kjennetegn ved grunnskolelærerutdanningen i Norge er at opplæringen foregår både gjennom teoriundervisning på campus og praksisopplæring noen uker hvert semester i grunnskolen. Det skal legges til rette for en studiesituasjon preget av helhet og sammenheng for lærerstudentene (UHR, 20I8), men det er et kjent dilemma at det for lærerstudenter kan være vanskelig å forstå forbindelsen mellom opplæring på campus og på praksisskole. Det kan være utfordrende å transformere kunnskap mellom de ulike læringskontekstene (Eraut, 2004; Fosse, 2016). For å utvikle pedagogisk kunnskap er det vesentlig å kunne oppdage - og reflektere over - mulige koblinger mellom teori og praksis, der både erfaringer fra praksis, kunnskap utviklet fra disse erfaringene og mer generelle teorier trekkes inn (Eide, Brekke \& Holthe, 20I7). Det vil derfor alltid være nødvendig for oss som faglærere i pedagogikk å ta stilling til hvordan teori og praksis kan integreres og inngå i et samspill i utdanningen. Gjennom praksisnær undervisning kan det skapes sammenheng mellom liv og lære, og forståelse både gjennom nærhet og avstand (Halvorsen, 2020). Ifølge Sætra (2018) er pedagogisk teori av stor betydning for å kunne fortolke det som skjer i praksis, og selvopplevde erfaringer som utgangspunkt for undervisning kan bidra til å skape mening og opplevelse av relevans for lærerstudenter (Hatlevik, 20I8; Nordkvelle, 2020).

Utgangspunktet for artikkelen er en kvalitativ studie (Brekke \& Eide, 20I9), der studentenes læringsprosess i arbeid med praksisfortellinger ble undersøkt på første trinn i

*Författarkontakt: mle@hvl.no

Artiklar och reflektioner är kollegialt granskade. Övriga bidragstyper granskas av redaktionen. Se https://hogreutbildning.se ISSN 2000-7558

(C)2021 Marianne Leikvoll Eide and May-Britt Revheim Brekke. This is an Open Access article distributed under the terms of the Creative Commons Attribution-NonCommercial 4.0 International License (https://creativecommons.org/licenses/by-nc/4.0/), allowing third parties to share their work (copy, distribute, transmit) and to adapt it, under the condition that the authors are given credit, that the work is not used for commercial purposes, and that in the event of reuse or distribution, the terms of this license are made clear.

Citation: Eide, M. L. \& Brekke, M.-B. R. (2021). «Fortelling fra praksis som inngang til pedagogisk kunnskap. Praksisfortelling som undervisningspraksis og laringsform i larerutdanningen", Högre utbildning, 11(2), 14-20. http://dx.doi.org/10.23865/hu.v11.2754 
grunnskolelærerutdanningen i Norge. Studentenes muntlige fremlegg av fortellinger, teoretiske innspill, respons på innspill, drøfting og refleksjon ble undersøkt gjennom deltakende observasjon. Slik undervisning krever sensitivitet; for selv om læringsarbeidet er godt strukturert og forberedt, så skal det være rom for studentenes egen tenkning. I denne artikkelen ser vi på erfaringer og funn fra den tidligere studien med et nytt blikk, særlig ut fra vårt perspektiv som faglærere i lærerutdanningen. Problemområdet vi ønsker å drøfte og reflektere over, er: Hvordan kan studentenes fortellinger fra praksis fungere som en god læringsform i pedagogikkundervisningen på campus, der det skapes sammenheng mellom egne erfaringer og teori?

Arbeidet med å koble praktiske erfaringer og teoretisk kunnskap er ikke noe nytt i lærerutdanningen (Hatlevik, 20I8; Holmbukt \& Son, 20I7; Lappalainen \& Schwarz, 20I4; Nordkvelle, 2020; Sætra, 2018), men tvert imot en vedvarende utfordring. Det er derfor av betydning å utveksle erfaringer og refleksjoner fra konkrete undervisningsopplegg som kan være av interesse ut over den partikulære konteksten.

\section{PRAKSISFORTELLING SOM LÆRINGSFORM I UTDANNINGEN}

Etter hver praksisperiode har studentene med seg selvopplevde erfaringer som de kan sette ord på, tolke og innlemme i den teoretiske undervisningen på campus. En praksisfortelling er, ifølge Mørch (2004): «... en fortelling om sentrale og utvalgte hendelser fra hverdagslivet $\mathrm{i}$ en organisasjon, opplevd og fortalt av de mennesker som arbeider i denne praksis.» For grunnskolelærerstudenter er erfaringene hentet fra praksisskolens hverdagsliv. Gjennom narrativer formidles noe som er lært gjennom erfaring (Kvernbekk \& Frimansson, 2013), og ifølge Fennefoss og Jansen (2004) er praksisfortellingen en fortolkning av erfaringen som for fortelleren er en reell situasjon. Det å sette ord på egne erfaringer kan bidra til å skape økt bevissthet om situasjoner som lærerstudenter har opplevd (Gudmundsdottir, 1996).

Gjennom egen aktivitet og erfaring er studentene dermed med på å konstruere sin egen kunnskap, og det skjer en personlig forståelse av situasjonen. Ifølge Dewey (1933) er erfaringsnærhet en forutsetning for læring, men det er samtidig ikke nok. Både utfordring av meningsperspektiver og kritisk refleksjon må til for at læring kan skje (Mezirow, 1990).

Praksisfortelling som leringsform i undervisningen vil i denne sammenhengen si at vi har utarbeidet et helhetlig faglig opplegg som omfatter observasjon, utarbeiding av praksisfortelling, og presentasjon av praksisfortellinger med teoretiske innspill i klassen på campus etter praksis. Vi søkte å åpne studentenes klasserom for refleksjon og drøfting i læringsfellesskapet på bakgrunn av tolkning og analyse av praksisfortellingene. Halmrast, Taarud \& Østerås (2013) har forsket på bruk av praksisfortellinger i barnehagelærerutdanningen i Norge. De peker på at synliggjøring av meningsforskjeller og meningsbryting i læringsfellesskap har betydning som grunnlag for endringsprosesser. For å utvikle profesjonskompetanse er det sentralt å utvikle evne til kritisk refleksjon over egnes og andres antakelser knyttet til profesjonsutøvelse (Hatlevik, 20I8). Pedagogisk teori beskriver og forklarer fenomener i verden og problematiserer pedagogiske problemstillinger (Kvernbekk, 200I), og i samspill mellom teori og refleksjon over egne og andres erfaringer kan selvstendig pedagogisk kunnskap utvikles hos studentene.

I det følgende drøftes noen utvalgte funn og egne erfaringer fra arbeidet med praksisfortelling som læringsform.

\section{UNDERVISNINGSOPPLEGG OG GJENNOMFØRING}

I et av arbeidskravene på I. trinn i grunnskolelærerutdanningen, i faget «Pedagogikk og elevkunnskap", arbeidet vi med praksisfortelling som en læringsform. Læringsprosessene i det 


\section{Marianne Leikvoll Eide \& May-Britt Revheim Brekke}

faglige opplegget var knyttet både til teoriundervisningen og praksisopplæringen. Bakgrunnen for valget er studentenes behov for å forstå sammenhenger mellom praktiske erfaringer og generalisert pedagogisk kunnskap.

Etter inspirasjon av Allas, Leijen \& Toom (2017), utformet vi et systematisk opplegg i flere faser. I løpet av praksisperioden skulle hver praksisgruppe utarbeide en praksisfortelling, med utgangspunkt i en felles observasjon i en praksisklasse. Studentgruppen sin oppgave, etter å ha observert, var å omarbeide en saklig observasjon til en fortelling fra praksis. I denne forbindelse fikk studentene undervisning både om observasjon som metode og om praksisfortelling som formidlingsform og læringsverktøy. Studentgruppene ble oppfordret til å vise et «innenfraperspektiv» i fortellingene, slik at deres egen historie fra klasserommet kom til uttrykk.

I den første undervisningsøkten etter praksisperioden skulle fortellingene formidles for klassen, og hver student på praksisgruppen skulle legge frem et teoretisk perspektiv som kunne belyse fortellingen. Målet var å se den valgte situasjonen ut fra ulike perspektiv, og relatert til teoretisk kunnskap. Slik ble en og samme fortelling tolket i lys av ulike teoretiske begreper og perspektiv.

Etter studentgruppens presentasjon ble det åpnet opp for innspill og refleksjon fra klassen og fra faglærer. Hensikten var å åpne rommet for nye tolkningsmuligheter, denne gangen fra et «utenfra-perspektiv». På denne måten kunne forforståelser og den første umiddelbare tolkningen av en praktisk situasjon i klasserommet endres.

\section{ERFARINGER OG FUNN FRA EGET ARBEID MED PRAKSISFORTELLINGER}

Mange av studentenes fremlegg tok utgangspunkt i situasjoner i praksis som kunne oppleves som krevende for dem; for eksempel utfordringer relatert til klasseledelse, uro og problematferd. En omarbeidet og forkortet fortelling kan tjene som eksempel på studenters erfaringer:

\section{Vi har nettopp begynt undervisningen i praksisklassen. For å få til god, tydelig klasseledelse må elevene vite hvem som er sjefen. \\ Det viste seg à vare enklere sagt enn gjort $i$ denne lese-timen. Støynivået er høyere enn forventet. Vi studenter hysjer på elevene, ber dem komme til ro. En elev knipser en annen elev i hodet. En av studentene gir eleven beskjed om å flytte seg hvis hun ikke kommer til ro. Eleven fortsetter à mase, gjor de andre rundt seg ukonsentrert. Studenten gir nye beskjeder, men eleven bare fortsetter.}

Studentgruppenes ulike fortellinger fungerte som startpunkt for videre fortolkninger i undervisningen. Hver praksisfortelling ble fulgt opp med forskjellige teoretiske innspill fra hver student i praksisgruppen. Innspillene etter presentasjon av eksempelfortellingen over, viste et skifte i fokus - fra elevenes atferd til lærerens forstålse av situasjonen; fra teknikker for å forme elevens atferd til elevens manglende motivasjon og over til lærerens danningsoppdrag og forståelse av eleven som subjekt.

Dersom undervisningsmetoden var arbeid med case, ville det vært viktig å komme med konkrete innspill til løsninger. Men intensjonen med praksisfortelling som læringsform er en annen: Målet her er ikke å komme til en løsning, ett svar, men å skape bevissthet - lære å løfte det som skjer ut av situasjonen og over til noe mer generelt. Denne læringsformen fungerer da som en viktig øvelse i å utsette løsningsforslagene til kunnskapsgrunnlaget er nøye gransket. Hvis løsningsforslag aksepteres med det samme, har vi, ifølge Dewey (I9IO), ukritisk tenkning, og etter hans syn det minimale av refleksjon. Han peker på betydningen av å komme frem til kloke 
løsninger gjennom god tenkning, dvs. å studere problemer nøye, stadig søke etter ny kunnskap, videreutvikle ideer, og reflektere over om antakelsene vi har er relevante og holdbare, eller ikke.

Dersom man ikke har for vane å forfølge ideer som oppstår, så vil man få det Dewey kaller «en gresshoppelignende gjetting» (IIIO, s. 66). I lærerutdanningen bør det derfor vektlegges, i tråd med Deweys ideer, å innarbeide en vane for reflektert og kritisk tenkning rundt praksis, som en bevegelse mellom observasjon og refleksjon. Å utvikle slik reflekterende erfaring er avgjørende for videre læring og danning (Burman, 20I4), og kan støtte studentene i deres yrkespraksis.

\section{Engasjement og gjenkjennelsesfaktoren}

Våre funn viser at det å fortelle, og det å dele fortellinger, skapte et engasjement og en involvering i undervisningen, noe som tydet på at studentene opplevde aktiviteten som relevant for dem. Studentene lyttet oppmerksomt til situasjoner og opplevelser som ble formidlet fra de andre studentene sine praksiskontekster, og kom med innspill og spørsmål både om hendelsene i seg selv, men også om hvordan disse kunne forstås og tolkes.

Fortellinger som skapte gjenkjennelse bidro i særlig grad til engasjement. Ifølge Hatlevik (2018) er det lettere «å koble seg på» fortellinger man kan kjenne seg igjen i, noe som kan bidra til at refleksjonen settes i sving og motivasjon for deltakelse øker. Historier gir gjenklang hos dem som lytter, sier Gudmundsdottir (1996). Hun beskriver hvordan bilder kan dukke opp i minnet gjennom andres ord, og føre til en «re-storying» der man setter sine egne erfaringer fra klasserommet inn i historien, og gjennom dette skaper sin egen fortelling.

\section{Egne erfaringer kan også by på utfordringer}

Den subjektive opplevelsen når man selv forteller, og når man lytter til en fortelling, bidrar til meningsskaping. Praksisfortellingens «innenfra-perspektiv» gir fortellingen styrke og kraft. En forklaring på dette kan være at førstehåndserfaringer skaper engasjement fordi de er personlige, og involverer både sanser og følelser (Kvernbekk, 20oI). Men når historienes utgangspunkt er studentenes subjektive erfaringer, kan tematikken komme til å bli værende i den nære konteksten.

Studentene kan, gjennom arbeidet med å bearbeide og tolke erfaringene, utvikle et eierforhold til «sine» fortellinger, og dermed ha et ønske om å forsvare og beholde disse. Vi observerte at en del studentgrupper fortsatt levde seg inn i sine egne opplevelser av situasjonen de hadde fortalt om, og ønsket å utbrodere videre egne reaksjoner og følelser. Det er viktig å anerkjenne betydningen slike førstehåndserfaringer kan ha for studentene, slik vi ser det. Men pedagogikkens fenomener kan bare ses indirekte (Kvernbekk, 200I), derfor vil det være behov for generaliserte teorier og begreper for å kunne kjenne igjen, forstå og drøfte pedagogiske problemstillinger. Utfordringen for oss som faglærere ble å holde engasjementet ved like ved å anerkjenne opplevelsene, og samtidig få fremdrift i å utvide forståelse av fortellingene i lys av teori.

\section{Teoriens rolle $i$ arbeid med pedagogiske problemstillinger}

Våre observasjoner viser at studenter ved starten av sin pedagogiske utdanning kan ha en uklar forståelse av teoriens rolle. Teorien kan ha ulike funksjoner; den kan begrunne, forstå, forklare og/eller oppdage nye sider ved praksis (Kvernbekk, 20oI). Kanskje har vi som lærerutdannere tatt for gitt at studentene ser disse funksjonene av seg selv. Derfor er det viktig at studentene gjennom undervisningen får kjennskap til hva pedagogisk teori er og kan være, og hvilken rolle den kan ha i en profesjonsutdanning. Praksisfortelling, som del av et faglig opplegg, ble derfor en praktisk øvelse i å løfte det partikulære over til noe mer generelt, da undervisningsøkten 
ikke stoppet etter studentenes subjektive historier. Vi observerte at kravet om et eget teoretisk innspill bidro til å fremme en form for pendelbevegelse mellom det induktive og det deduktive, som ifølge Dewey (2010) kan bidra til å fremme helhetsforståelse og kritisk tenkning.

Som tidligere omtalt dreide flere av fortellingene seg om utfordringer studentene møtte i undervisningen, for eksempel det å håndtere utagerende atferd. Hovedfokus i det første året er lærerrollen og tilrettelegging for læring, og det betyr at studentene ikke har teori eller undervisning knyttet spesifikt til atferdsutfordringer som tema. Det kunne dermed bli vanskelig for studentene å trekke inn relevant teori. For oss faglærere oppstod et dilemma: Vi ønsket at studentene skulle fortelle om det som opptar dem, for at arbeidskravet skulle oppleves som meningsfullt og relevant for dem, og samtidig kunne dette bli problematisk når intensjonen er å forstå praksisfortellingen i lys av teori.

\section{Utfordring av vanetenkning}

Mange fortellinger dreide seg om uro i klasserommet, og opplevelse av krevende møter med en mangfoldig elevgruppe. Vi observerte at studentene kunne bli både engasjerte og frustrerte da vi, som faglærere, problematiserte vanetenkning - som for eksempel kategorisering av elever som henholdsvis «svake», «sterke», eller som «problemelever».

Det er en viktig øvelse, både for faglærere og medstudenter, å komme med kritiske innspill som kan sette refleksjonen i sving, slik at meningsperspektiver og vanetenkning blir utfordret (Mezirow, 1990). For at ny forståelse og tenkning kan skje, er det vesentlig at studentene tør å delta aktivt i klassesamtalen. Mulighetene for refleksjon i fellesskapet avhenger av både klima og læringskultur i klassen. Et godt klima for refleksjon må utvikles i hver kontekst for at et godt samspill kan oppstå. Som faglærere må vi balansere forholdet mellom utfordring og støtte (Zackarasson, 2019), slik at studentene kjenner seg trygge på å bidra både med fortellinger, tolkninger og spørsmål. Samtidig må vi tørre å stille utfordrende spørsmål hvis det skal utvikles nye forståelsesmåter. Her kan flere forhold påvirke klimaet; dette kan både dreie seg om hvordan vi som faglærere stiller spørsmål, og om hvor godt kjent studentene er med medstudenter og underviser. Det er også et vesentlig poeng at vi klarer å formidle til studentene betydningen av å få utfordret egen tenkning, for læring.

Vårt undervisningsopplegg var knyttet til et arbeidskrav. Alle studenter måtte delta og gjøre en innsats for å få arbeidskravet vurdert som bestått i tråd med gitte vurderingskriterier. Som faglærere søkte vi å tone ned vurderingsaspektet i selve læringsøkten, for å sette læringsaktiviteten i fokus. Studenters refleksjon og kritiske holdning til egne erfaringer kan bli hemmet dersom studentene blir for opptatt av at de blir vurdert (Rappel, 20I8). Til tross for at vi overfor studentene vektla læringsaspektet i refleksjonsøkten, fremstod en del studenter spente før de selv skulle presentere. Som faglærere må vi derfor ta inn over oss at lytting og deling av perspektiver for enkelte kan bli skjøvet i bakgrunnen når det summative og kvalifiserende aspektet får dominere, selv om vår hensikt var en annen. I ettertid har vi derfor søkt å tydeliggøøre i enda større grad at deltakelse i alle deler av arbeidskravet i seg selv kvalifiserer for å få bestått.

\section{REFLEKSJONER OG AVSLUTTENDE KOMMENTAR}

Når studentene er tilbake på campus etter praksisoppholdet sitt, møtes alle praksisgruppene og hver fortelling løsrives da fra sin opprinnelige kontekst. Samtalen dreier seg ikke lenger bare om det partikulære, dermed kan konstruksjon av kunnskap utvides fra å gjelde den enkelte til å gjelde alle involverte i samtalen. Erfaringen heves da fra det konkrete til et mer abstrakt nivå. Slik fikk studentene et mer breispektret erfaringsgrunnlag å teoretisere ut fra. Vi observerte 
at studentenes selvopplevde erfaringer gav en positiv dimensjon til undervisningen, i form av involvering og engasjement. Men det kan være vanskelig å løfte blikket fra den opprinnelige fortellingen, og det så ut til at noen følte behov for å forsvare denne. Vår oppgave blir å tydeliggjøre at det ikke dreier seg om hvordan den konkrete situasjonen skal løses, men heller at den fungerer som et grunnlag for å diskutere pedagogiske problemstillinger.

Praksisperioden kan for studenter fremstå som den viktigste kilden til forståelse av lærerarbeid, og derfor kan egne erfaringer gi en gyllen inngang til utvikling av pedagogisk kunnskap. Men praksisfortelling som læringsform er en ambisiøs og utfordrende læringsprosess, da den involverer lag på lag av ulike prosesser. Det er et tidkrevende arbeid, som forutsetter at studentene har kunnskap om observasjon som metode, kjennskap til praksisfortelling som sjanger, og at de deltar i et refleksjonsfellesskap hvor de både presenterer eget arbeid og responderer på andres. For oss faglærere gjelder det derfor å skissere opplegget så strukturert, tydelig og klart som mulig for studentene.

Resultat av undervisning er aldri gitt på forhånd, og spesielt ikke når undervisningen søker å fremme transformative læringsprosesser som er nært knyttet til studentenes egen identitetsutvikling som fremtidige lærere. Studentenes innsikt og forståelse vil utvikles i egen takt og rytme hos hver lærerstudent ut fra den enkeltes bakgrunn og aktuelle ståsted, selv om de alle er førsteårsstudenter. Opplegget med praksisfortelling som start- og sentreringspunkt gir rom for å modellere ulike måter å bruke teorier på i forbindelse med fortellingene. Dette kan gi en god støtte til «ferske» studenter. Refleksjonsøkten kan samtidig utfordre og stimulere til selvstendiggjørende læringsprosesser, der en kritisk og reflektert væremåte aktiveres og modelleres, under forutsetning av at læringsmiljøet «tåler» konstruktiv meningsbrytning og utfordring av vanetenkning.

Vi konfronteres også med en annen utfordring i denne refleksjonsøkten: Hvordan kan vi på den ene siden anerkjenne studentenes innspill, egne fortolkninger og frie tanker, uten å respondere med evaluerende tilsvar, og på den andre siden respondere på en måte som bringer studentenes kritiske tenkning videre? Deling av kunnskap forutsetter at studentmangfoldet forstås som en ressurs, der vi som faglærere ikke forventer «rette» svar på problemstillinger som løftes frem. $\AA ̊$ være bevisst sin egen respons på studentenes innspill, er lettere sagt enn gjort. Det oppleves som avgjørende å være oppmerksomt, kritisk og konsentrert til stede, og vår evne til å utvise sensitivitet overfor studentene utfordres i situasjonen. Klassesamtalen i refleksjonsøkten blir på denne måten en god øvelse i balansekunst for oss som faglærere.

\section{FORFATTERPRESENTASJONER}

May-Britt Revheim Brekke er høgskolelektor i pedagogikk ved Høgskulen på Vestlandet. Hennes forskningsinteresser er knyttet til allmenne pedagogiske problemstillinger, særlig med fokus på teori og praksis, refleksjon og transformativ læring.

Marianne Leikvoll Eide er høgskolelektor i pedagogikk ved Høgskulen på Vestlandet. Hennes forskningsinteresser er relatert til allmenne pedagogiske problemstillinger, med særlig oppmerksomhet rettet mot teori/praksis-forholdet i lærerutdanningen, refleksjon og transformativ læring.

\section{LITTERATUR}

Allas, R., Leijen, Ä. \& Toom, A. (20I7). Supporting the construction of teacher's practical knowledge through different interactive formats of oral reflection and written reflection. Scandinavian Journal of Educational Research, 6I(5), 600-6I5. https://doi.org/I0.1080/00313831.2016.1172504 


\section{Marianne Leikvoll Eide \& May-Britt Revheim Brekke}

Brekke, M-B. R. \& Eide, M. L. (2019). Praksisfortelling, refleksjon og transformativ læring. Acta Didactica Norge, I3(3). https://doi.org/I0.5617/adno.6910

Burman, A. (20I4). Dewey og den reflekterande erfarenheten. I A. Burman (Red.), Den reflekterade erfarenheten: John Dewey om demokrati, utbildning och tänkande (s. 13-36). Huddinge: Södertörns högskola.

Dewey, J. (1910). How We Think. Project Gutenberg. https://www.gutenberg.org/ebooks/37423

Dewey, J. (1933). How we think: A restatement of the relation of reflective thinking to the educative process. Boston: D. C. Heath and Company.

Eide, M. L., Brekke, M-B. R. \& Holthe. A. (2017). Teoriens manglende plass i praksissamtalen. Acta Didactica Norge, II(I). https://doi.org/I0.56I7/adno.3985

Eraut, M. (2004). Transfer of knowledge between education and workplace settings. I H. Rainbird, A. Fuller \& A. Muro (Red.), Workplace learning in context (s. 20I-22I). London: Routledge.

Fennefoss, A. T. \& Jansen, K. E. (2004). Praksisfortellinger - på vei til innsikt og forståelse. Bergen: Fagbokforlaget.

Fosse, B. O. (20I6). Transformering av kunnskap mellom campus og skole i lærer-utdanningen. Acta Didactica Norge, Io(2). https://doi.org/I0.5617/adno.2498

Gudmundsdottir, S. (1996). The teller, the tale and the one being told: The narrative nature of the research interview. Curriculum Inquiry, 26(3), 293-306.

Halmrast, G., Taarud, R. \& Østerås, B. (2013). Bruk av praksisfortellinger for å skape sammenheng mellom praksis og teori i førskolelærerutdanningen. Norsk pedagogisk tidsskrift, 97(I), I7-27.

Halvorsen, G. S. (2020). Hva kan praksisnær undervisning være? I Y. T. Nordkvelle, L. Nyhus, A. Røisehagen \& R. H. Røthe (Red.), Praksisnar undervisning - i praksis og teori (s. 33-52). Oslo: Cappelen Damm Akademisk.

Hatlevik, I. K. R. (2018). Transformativ læring. Uniped, (4), 384-40o.

Holmbukt, T. E. \& Son, M. (2017). Praksisnær lærerutdanning - et eksempel fra engelskfaget. Tidsskriftet FoU i praksis, 2, 75-93.

Kvernbekk, T. (200I). Erfaring, praksis og teori. I T. Kvernbekk (Red.), Pedagogikk og larerprofesjonalitet (s. I46-I63). Oslo: Gyldendal Akademisk.

Kvernbekk, T. (200I). Om pedagogikkens faglige identitet. I T. Kvernbekk (Red.), Pedagogikk og larerprofesjonalitet (s. 5-I2). Oslo: Gyldendal Akademisk.

Kvernbekk, T. \& Frimannsson, G. H. (2013). Narrative: A brief introduction. Scandinavian Journal of Educational Research, 57(6), 57I-573.

Lappalainen, J. H. \& Schwarz, E. (20I4) Konsten att lära av erfarenheten. I A. Burman (Red.), Den reflekterade erfarenheten: John Dewey om demokrati, utbildning och tänkande (s. 99-II3). Huddinge: Södertörns högskola.

Mezirow, J. (1990). How critical reflection triggers transformative learning. I J. Mezirow (Red.), Fostering critical reflection in adulthood: A guide to transformative and emancipatory learning (s. I-2I). San Francisco: Jossey-Bass.

Mørch, S. (2004). Padagogiske praksisfortallinger. Århus: Systime Academic.

Nordkvelle, Y. (2020). Praksisnær undervisning - nytt begrep og ny realitet? I Y. T. Nordkvelle, L. Nyhus, A. Røisehagen \& R. H. Røthe (Red.), Praksisnar undervisning - i praksis og teori (s. 7-3I). Oslo: Cappelen Damm Akademisk.

Rappel, L. (2018). Transforming thought through reflective experiential learning. Arts and Humanities Open Access Journal, 2(2), I3I-136.

Sætra, E. (2018). Om forholdet mellom teori og praksis i lærerutdanning. Norsk pedagogisk tidsskrift, (4), 340-350.

Universitets- og høgskolerådet [UHR]. (20I8). Felleskapittel - nasjonale retningslinjer for lærarutdanningane. Hentet 20.0I.202I fra https://www.uhr.no/_f/pi/i4fbdogeo-6a5f-4ai3-9e89-397Ic57cfasd/ fellestekst-for-retningslinjene-for-alle-typer-av-larerutdanning.pdf

Zackariasson, M.(2019). Balansen mellan att uppmuntra och ställa krav. En reflektion över studenters uppsatsskrivande i relation till stress och stöttning. Högre Utbildning, 9(2), 15-24. https://doi.org/ I0.23865/hu.v9.I662 